\title{
Grammonus nagaredai, a New Viviparous Marine Fish (Ophidiiformes: Bythitidae) from the Hawaiian Islands ${ }^{1}$
}

\author{
Fohn E. Randall ${ }^{2,3}$ and Marc Fames Hughes ${ }^{4}$
}

\begin{abstract}
Grammonus nagaredai is described as a new species of viviparous bythitid fish from two specimens collected from caves off $\mathrm{O}^{\prime}$ ahu and Hawai'i at depths of 6-9 m. Grammonus yunokawai Nielsen, known from one specimen from a cave in $20 \mathrm{~m}$ in the Ryukyu Islands, is the most similar species, differing in having a deeper body, more convex nape, broader maxilla, longer predorsal length, and shorter pectoral fins.
\end{abstract}

The Ophidifformes includes the cuskeels (Ophidiidae), viviparous brotulas (Bythitidae), and the pearlfishes (Carapidae), all with species found in the Hawaiian Islands. Six described species of bythitids are reported from the Islands (Mundy 2005), one in the genus Grammonus Gill, G. waikiki (Cohen). It was described as Microbrotula nigra by Gosline (1953). When reclassified in genus Oligopus Risso, Gosline's species name was invalid as a homonym, so Cohen (1964) provided the new name $O$. waikiki in his revision of the six species of the genus. Oligopus was later shown to be preoccupied and was replaced by Grammonus by Nielsen et al. (1999).

The genus Grammonus is characterized by a relatively short body, fully covered by small cycloid scales; well-developed eyes; the maxilla expanded posteriorly, with a small ventral-projecting spine; no palatine teeth; a large tongue with a narrow projecting tip; 8 branchiostegal rays; $38-53$ vertebrae; a single pelvic ray; 8 or 10 caudal rays, joined at least basally to the dorsal and anal fins; and 3 or 4 long gill rakers on first gill arch.

Randall (2007:118) illustrated what he be-

\footnotetext{
${ }^{1}$ Contribution 2008-003 of the Hawaiian Biological Survey. Manuscript accepted 12 February 2008.

${ }^{2}$ Corresponding author (e-mail: jackr@hawaii.rr .com).

${ }^{3}$ Bernice P. Bishop Museum, 1525 Bernice Street, Honolulu, Hawai'i 96817-2704.

${ }^{4}$ P.O. Box 390414, Kailua-Kona, Hawaici 96745.
}

Pacific Science (2009), vol. 63, no. 1:137-146

(C) 2009 by University of Hawai'i Press

All rights reserved lieved to be an undescribed species of Grammonus that was photographed in a cave in $9 \mathrm{~m}$ off the Kona coast of the island of Hawai' $i$ in 1998 by Kendra Choquette. A photograph (Figure 1) was taken in 2003 by Marc James Hughes of a fish in the same cave (possibly the same individual as the one photographed in 1998), but the fish was not collected. When he became aware that the fish represented an undescribed species of bythitid, he revisited the cave, as well as other caves, but he did not collect a specimen until May 2007. The fish was sent alive to a pet store in Honolulu with instructions to pass it on to the Waikik $\overline{1}$ Aquarium, but it died and was discarded.

Bronson Nagareda was collecting aquarium fishes while reef walking at shore at a depth of about $1 \mathrm{~m}$ at Campbell Industrial Park, O'ahu, in early summer of 2007. When a butterflyfish darted under a ledge, he tried to catch it with a hand net. As he withdrew his net, it contained instead a bythitid fish. He sent it in the next shipment of live fish to Florida. When he realized later that it was the species of Grammonus for which no museum specimens are known, he tried to retrieve the fish, but it had also died and was not retained.

Marc James Hughes collected a second specimen of Grammonus from Kona in July 2007. Upon placing it in a small tank, the fish released numerous larvae about $3 \mathrm{~mm}$ in total length. This fish was preserved and successfully shipped to the Bishop Museum in Honolulu.

Nagareda collected his second specimen from a cave in $6 \mathrm{~m}$ off the coast of Wai'anae, O'ahu, on 10 August 2007. He took a series of photographs in his aquarium, preserved 


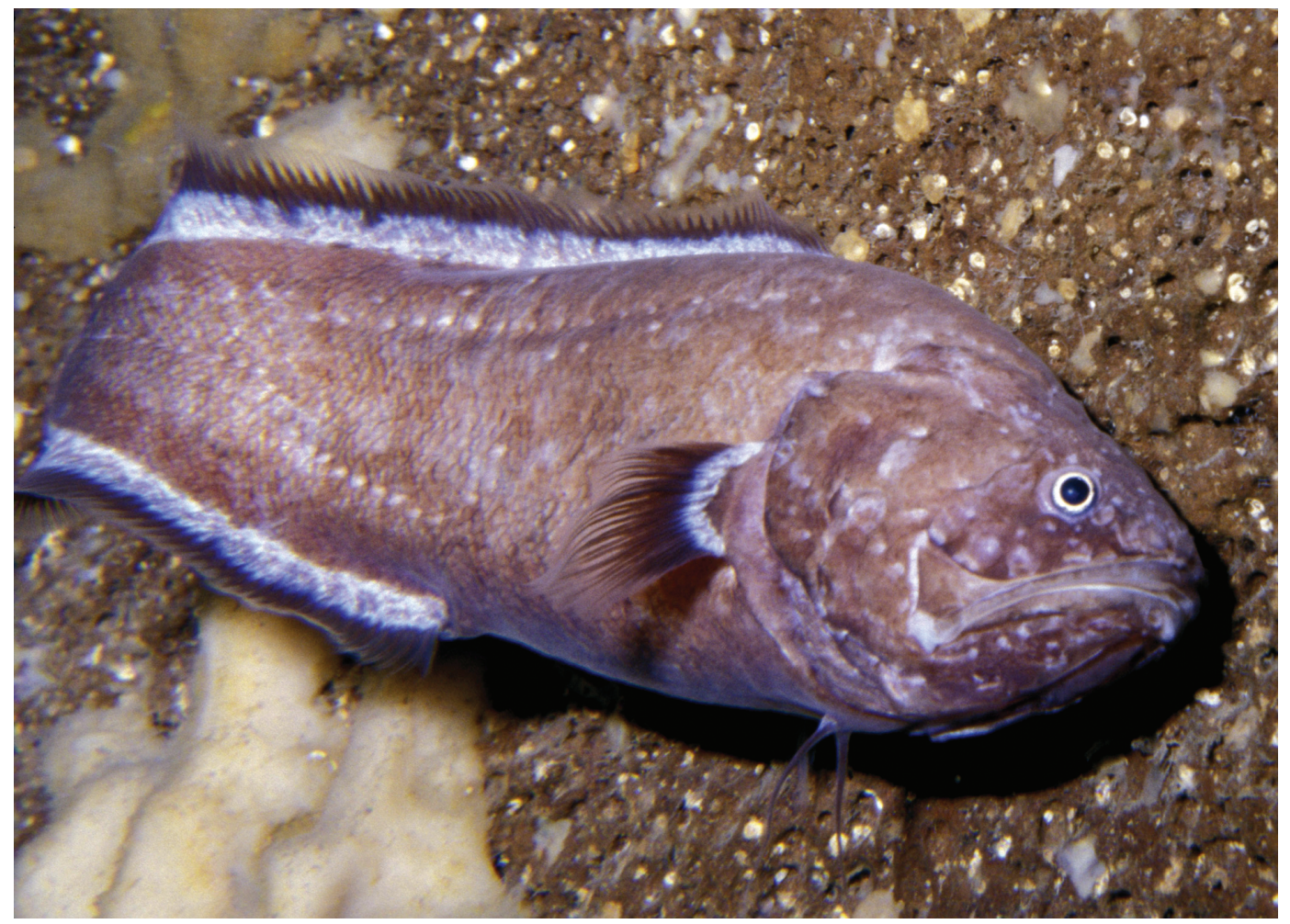

Figure 1. Underwater photograph of Grammonus nagaredai, Kona, Hawai'i, not collected (Marc James Hughes).

the fish, and donated it to the Bishop $\mathrm{Mu}-$ seum. With two specimens of this longsought fish available, the species is described here.

\section{MATERIALS AND METHODS}

The holotype is deposited in the Bernice P. Bishop Museum, Honolulu (врвм), and the paratype in the U.S. National Museum of Natural History, Washington, D.C. (USNM).

Lengths recorded for specimens are standard length (SL), measured from the front of the upper lip to the midbase of the caudal fin; body depth from the origin of dorsal fin, and body width at the upper base of the pectoral fins; head length from the front of the upper lip to the posterior end of the opercular membrane; head width is the maximum measurement with the gill covers fully closed; snout length is taken from the front of the upper lip to the nearest edge of the orbit; orbit diameter is the maximum width of the unpigmented part of the eye, and interorbital width the least fleshy width; upper-jaw length is measured from the front of the upper lip to the posterior end of the maxilla; maxillary depth is the greatest depth at the expanded posterior end, not including the small ventral-projecting spine.

The scales in longitudinal series are counted in oblique rows from the upper angle of the opercle to the midbase of the caudal fin (scale rows are divided in places, especially anteriorly, so recounts may differ by as many as three scales). Gill-raker counts were made on the first gill arch; developed and rudimentary rakers are distinguished. Vertebral counts do not include the hypural plate (following Cohen 1964).

Data in parentheses in the description refer to the paratype. Proportional measurements in the text are ratios with the standard 
TABLE 1

Proportional Measurements of Type Specimens of Grammonus nagaredai as Percentages of the Standard Length

\begin{tabular}{lcc}
\hline \hline & $\begin{array}{c}\text { Holotype } \\
\text { (в РвM }\end{array}$ & $\begin{array}{c}\text { Paratype } \\
\text { (USNM }\end{array}$ \\
Parameter & $40668)$ & $391918)$ \\
\hline Sex & Male & Female \\
Standard length (mm) & 82 & 106 \\
Body depth (dorsal-fin origin) & 29.7 & 31.1 \\
Body depth (anal-fin origin) & 26.3 & 25.5 \\
Body width & 13.7 & 14.7 \\
Head length & 31.7 & 31.4 \\
Head width & 15.9 & 16.7 \\
Snout length & 9.2 & 8.9 \\
Orbit diameter & 4.9 & 4.0 \\
Interorbital width & 8.8 & 8.6 \\
Caudal-base depth & 1.5 & 1.4 \\
Upper-jaw length & 18.5 & 18.4 \\
Height of maxilla & 6.9 & 7.1 \\
Predorsal length & 38.0 & 38.4 \\
Preanal length & 55.1 & 56.9 \\
Prepelvic length & 25.1 & 24.3 \\
First dorsal ray & Broken & 4.2 \\
Longest dorsal ray & 10.5 & 9.0 \\
First anal ray & 3.2 & 3.6 \\
Longest anal ray & 10.7 & 8.7 \\
Caudal-fin length & 14.1 & Broken \\
Pectoral-fin length & 19.6 & 19.3 \\
Pelvic-fin length & 14.0 & 14.9 \\
\hline & & \\
\hline
\end{tabular}

length, body depth, and head length, rounded to the nearest .05 .

\section{RESULTS AND DISCUSSION}

Grammonus nagaredai Randall \& Hughes, n. sp.

$$
\text { Figures 1-5; Table } 1
$$

Grammonus sp. Randall, 2007:118, fig. (Hawai'i).

TyPe MATERial: Holotype: вPвм 40668, $82 \mathrm{~mm}$, Hawaiian Islands, O'ahu, Wai'anae coast, off Kea'au Beach Park, cave in $6 \mathrm{~m}$, hand net, B. Nagareda, 10 August 2007.

Paratype: UsNm 391918, 106 mm, Hawaiian Islands, Hawai'i, Kona coast, about 0.5 $\mathrm{km}$ north of beach at Kona Paradise subdivision, $19^{\circ} 19^{\prime} 38.0^{\prime \prime} \mathrm{N}, 155^{\circ} 53^{\prime} 16.1^{\prime \prime} \mathrm{W}$, cave in $9 \mathrm{~m}$ (cave entrance $3 \mathrm{~m}$ from shore), caught by hand, M. J. Hughes, 21 July 2007.
Diagnosis: A species of Grammonus, with dorsal rays 86; anal rays 64-66; caudal rays 10; pectoral rays 23-24; longitudinal scale series 86-91; predorsal scales extending to interorbital space; scales present on opercle and preopercle; three overlapping longitudinal rows of prominent sensory papillae on body; vertebrae 42 ; body depth at origin of dorsal fin 3.2-3.4 in SL; head length 3.153.2 in SL; mouth strongly oblique; edge of preopercle smooth except for a tiny spine at rounded corner; caudal fin joined only basally to dorsal and anal fins; normal life color dark brown, the sensory papillae on head and body white.

DESCRIPTION: Dorsal rays 86, all branched, most to base; anal rays 64 (66), all except last branched, most to base; caudal rays 10 , branched distally; pectoral rays 23 (24), all branched; pelvic rays 1, with two closely adherent branches for about one-third length; longitudinal scale series 86 (91); scales above origin of anal fin to base of dorsal fin about 40; developed gill rakers 3 , one at angle and 2 on lower limb; rudimentary gill rakers $5+11(6+12)$; vertebrae $12+30$.

Body moderately deep, the depth at dorsal-fin origin 3.4 (3.2) in SL; body depth at anal fin origin 3.8 (3.9) in SL; body compressed, the width 2.15 in body depth; head length 3.15 (3.2) in SL; head width 2.0 (1.9) in head length; snout length 3.45 (3.5) in head length; orbit diameter 6.5 (7.85) in head length; interorbital width 3.6 (3.65) in head length; caudal-fin base 2.1 (2.25) in head length.

Mouth strongly oblique, forming an angle of about $30^{\circ}$ to horizontal axis of body, the lower jaw slightly projecting; mouth large, the maxilla extending halfway between posterior edges of orbit and preopercle, the upperjaw length 1.7 in head length; maxilla broadly expanded posteriorly, the hind edge straight with rounded corners; ventroposterior corner of maxilla with a small downward-projecting spine; width of maxilla (not including spine) 4.6 (4.55) in head length; upper jaw with a band of small villiform teeth in a maximum of about 10 rows, the width of band about twice as broad anteriorly as posteriorly; symphyseal gap between bands of teeth in upper 


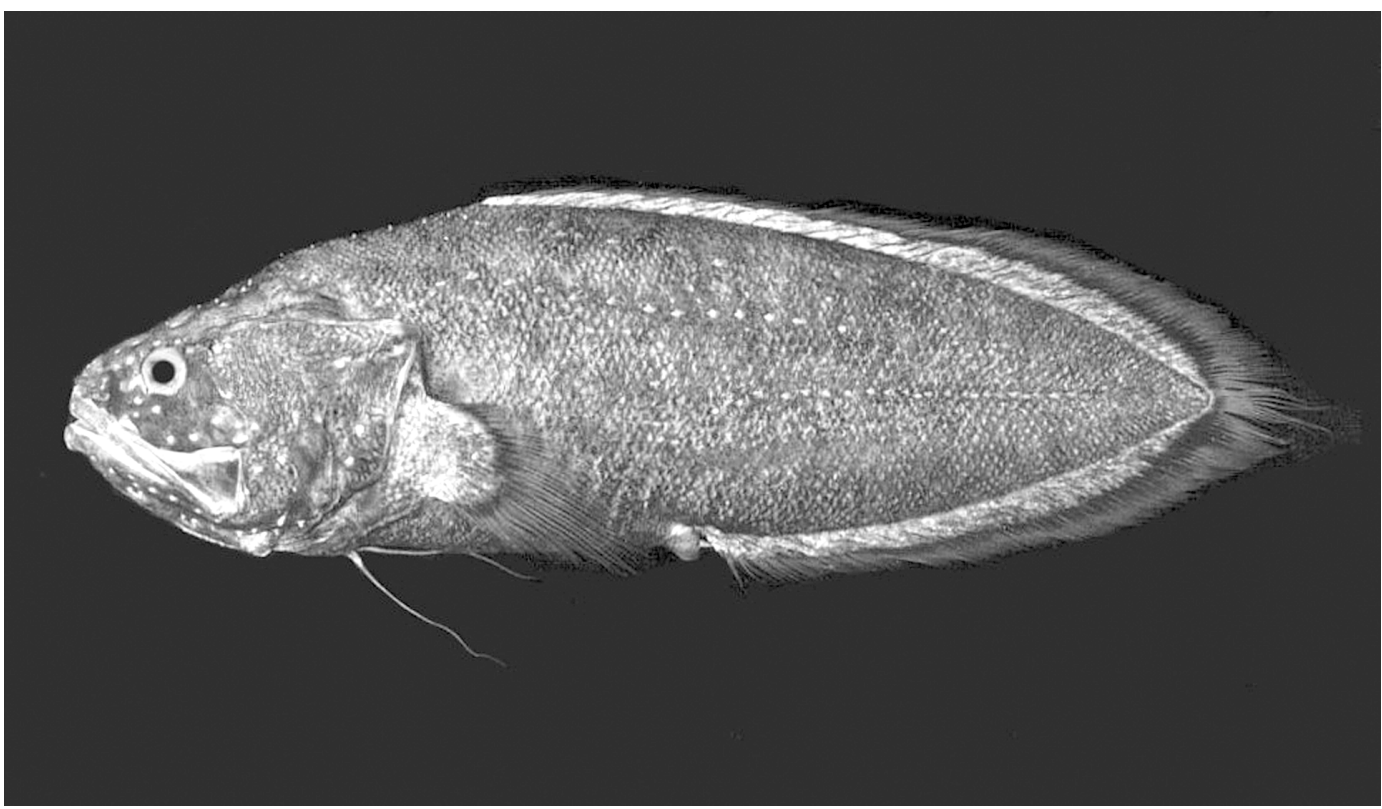

FigUre 2. Holotype of Grammonus nagaredai, врвм 40668, 82 mm SL, O‘ahu (J.E.R.).

jaw one-half orbit diameter; lower jaw with a similar villiform band of teeth but narrowing more and with the occlusal surface progressively more oblique posteriorly; innermost row of teeth in lower jaw two to three times longer than teeth of lateral rows, except anteriorly; symphyseal gap between bands of teeth in lower jaw about one-fourth that of upper jaw; a narrow, chevron-shaped band of villiform teeth on vomer; no palatine teeth; tongue broad, narrowing to a projecting tip anterior to vomer that nests in a fleshy groove when mouth closed.

An acute spine posteriorly on opercle at level of upper edge of orbit, the opercular flap centered above spine, extending about one-half orbit diameter posterior to spine tip; free margin of preopercle extending from level of front of upper jaw to above end of mandible, the margin smooth except for a very small spine at rounded corner.

Anterior nostril a short, broad, forwardprojecting tubule at level of lower edge of orbit just dorsal to groove above premaxilla; posterior nostril at edge of orbit before lower one-half of eye, the aperture oval, the maximum diameter equal to pupil.

Supraorbital canal of lateralis system with a large forward-projecting pore at front of base of anterior nostril and a small pore above nostril; infraorbital canal with a large ovate pore ventroposterior to base of anterior nostril, followed by five very large, strongly elliptical pores above dorsal edge of upper jaw; preoperculomandibular canal with a pair of round pores at front of mandible, followed by five large, slitlike pores, the last two at edge of preopercle.

Lateral line on body consisting of three longitudinal rows of sensory papillae, the uppermost from occiput along upper part of nape to below dorsal fin about halfway back in fin, with 10 papillae posterior to dorsal-fin origin; middle row beginning above operculum, consisting of 19 (20) papillae; lower row passing initially just below middle row, descending in an irregular path above and posterior to pectoral fin, and continuing with about 24 papillae from above origin of anal fin to posterior part of body. 


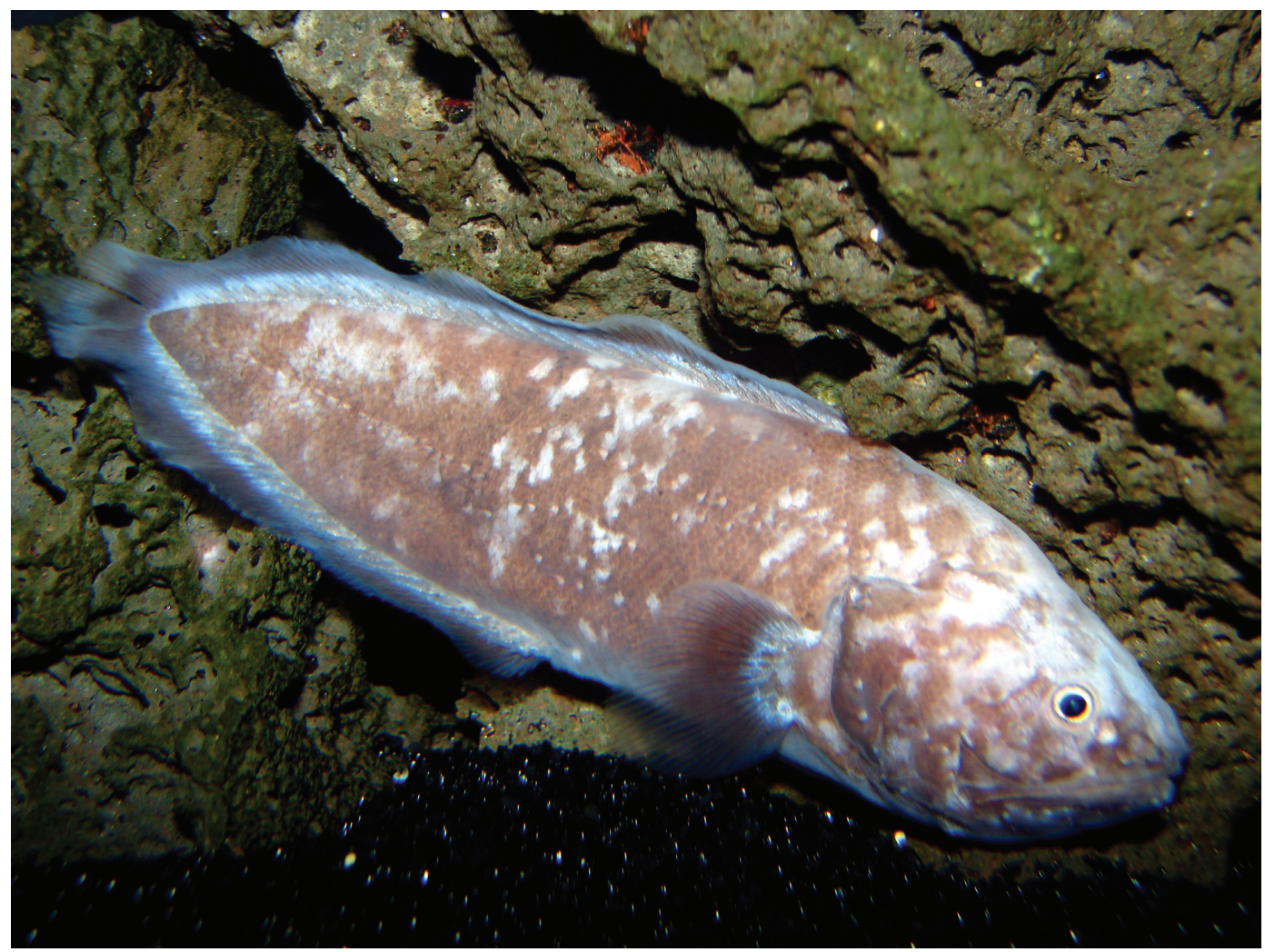

FIGURE 3. Aquarium photograph of holotype of Grammonus nagaredai (Bronson Nagareda).

Sensory papillae on head as conspicuous small white spots in life, including eight in a transverse ellipse dorsally on occiput, with two papillae inside.

Body fully covered with small, imbricate, cycloid scales, those on nape extending to interorbital space; operculum scaled except for a broad naked zone along free margin of preopercle; a broad naked zone between dorsal edge of opercle and scales of nape, consisting of a row of four circular fleshy depressions larger than pupil, with a fifth above second depression, resulting in a constriction of scales on nape, the narrow part 10 scales in width, preceded by 10 median scales of nape series; postorbital and suborbital region with six similar depressions; no scales extending out on median fins, the basal part of dorsal and anal fins with a broad fleshy zone; pre- pectoral area with small scales, the scales continuing in a pointed projection onto fin base in a maximum of 5 scales.

Origin of dorsal fin a little more than an orbit diameter posterior to head, the predorsal length 2.65 (2.6) in SL; first dorsal ray broken in holotype (of paratype 7.5 in head length); longest dorsal ray 3.0 (3.5) in head length; origin of anal fin below base of 25 th dorsal ray, the preanal length 1.8 (1.75) in SL; first anal ray 9.9 (8.65) in head length; longest anal ray 2.95 (3.6) in head length; caudal fin pointed, joined only basally to dorsal and anal fins, 2.25 in head length; pectoral fins pointed, the 15 th ray longest, 1.6 in head length; pelvic fins jugular, the prepelvic length 4.0 (4.1), the ray length 2.25 (2.1) in head length.

Male intromittent organ with a slender, 


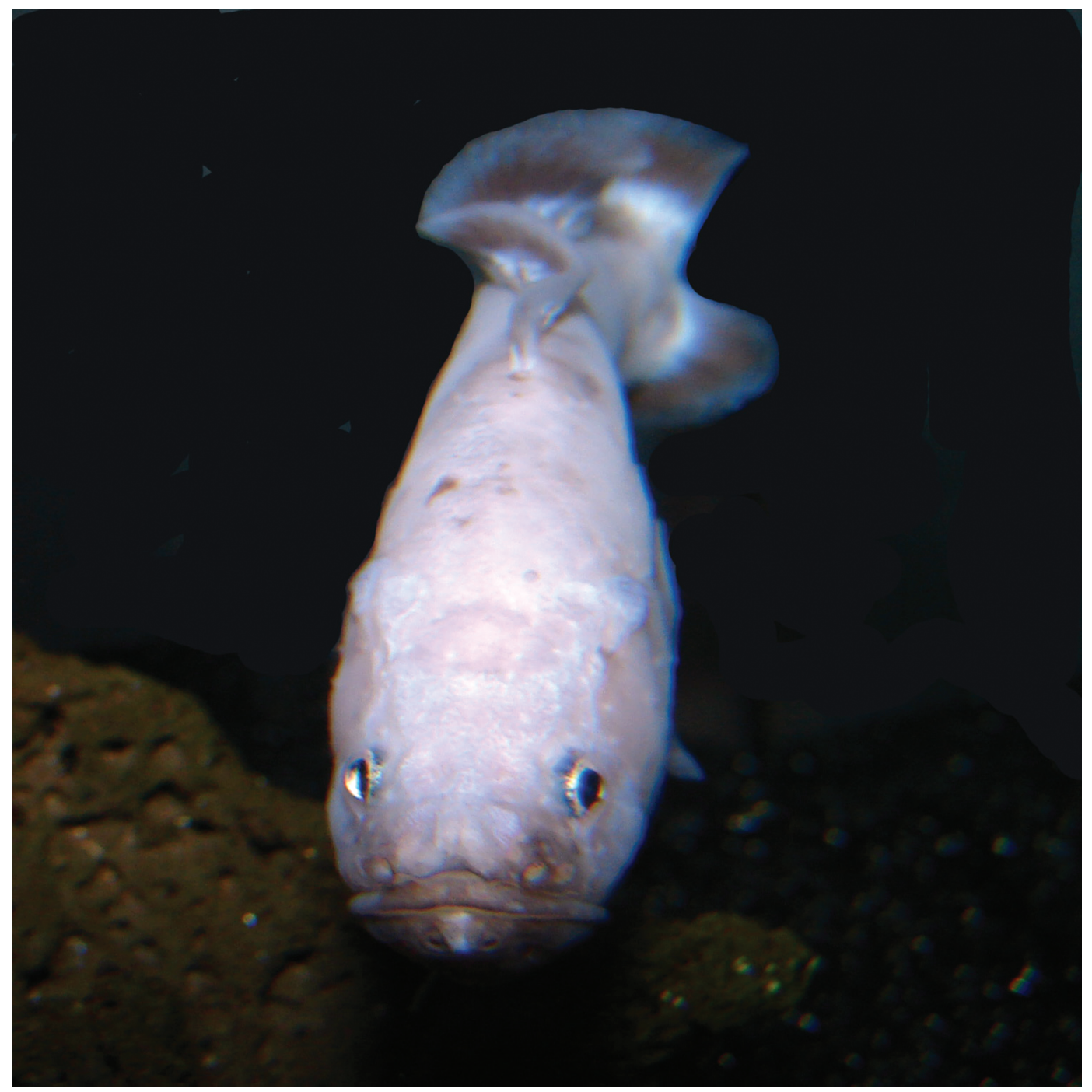

Figure 4. Aquarium photograph of holotype of Grammonus nagaredai (Bronson Nagareda).

pointed, white genital papilla as long as orbit diameter, protected by a fleshy protuberance except posteriorly.

Color of holotype in alcohol (Figure 2): Dark brown, the scale edges darker brown; sensory papillae white; basal half of dorsal and anal fins dark brown, the outer half with pale rays and membranes that grade from brown to translucent distally; caudal and pec- toral fins similar in color but dark brown only on extreme base; pelvic fins dark brown.

This species is usually dark brown in life, as in preservative, but when illuminated it quickly takes on a stress pattern of pale blotches (Figure 3), the base of the dorsal and anal fins partly pale bluish. With continued illumination, it becomes almost completely pale (Figure 4). 


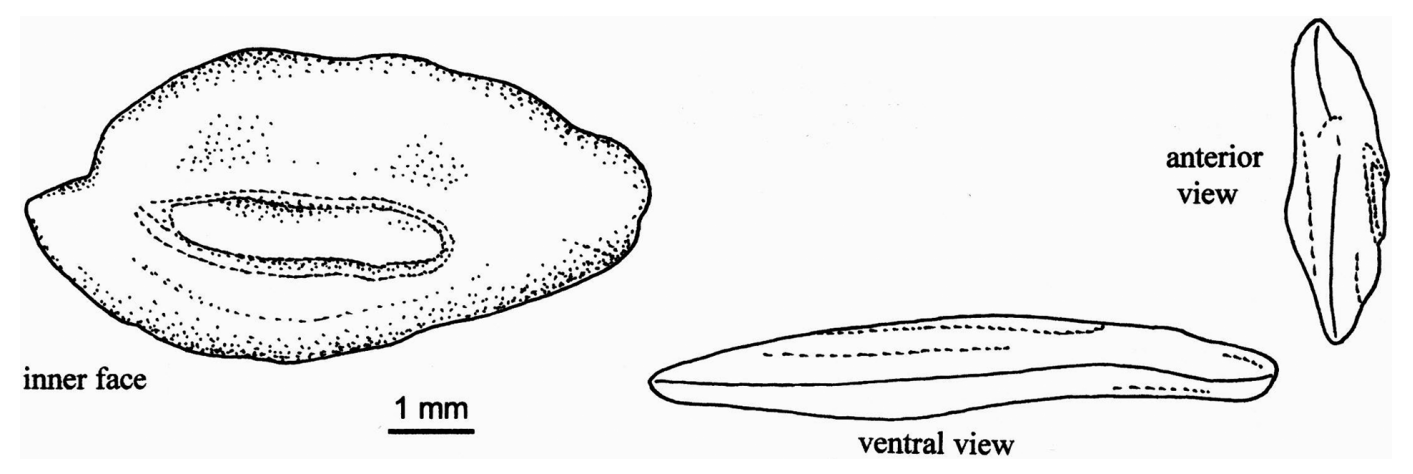

FIGURE 5. Otolith of paratype of Grammonus nagaredai (Werner Schwarzhans).

The following description of the otolith from the paratype was provided by Werner Schwarzhans: elongate and thin, the length to height 2.0; height to thickness, 3.2; dorsal and ventral rims undulate, without prominent angles; anterior tip more sharply pointed than posterior; inner face convex with markedly inframedian sulcus; sulcus not divided into ostium and cauda, with a single well-marked colliculum; outer face flat and smooth. His drawing of three views of the otolith is given as Figure 5. He also provided drawings of the otoliths of all the species of Grammonus (Figure 6).

COMPARATIVE MATERIAL: Grammonus robustus, zUMC P 77116 7-1168, 2: 85-110 mm, Gulf of Aden, Meteor Cruise 5, Station 287, 16 March 1987.

etrmology: We name this species Grammonus nagaredai in honor of Bronson Nagareda, who collected the holotype and provided a series of photographs taken in his aquarium.

REMARKS: Grammonus nagaredai would fall out in the key of Cohen (1964) and Nielsen et al. (1999) with $G$. ater (Risso) from the Mediterranean Sea, G. longhursti (Cohen) from West Africa, and the Indo-Pacific G. robustus Smith \& Radcliffe. Of these three, it is most similar to robustus, sharing the strongly oblique mouth and nearly the same fin-ray counts. It differs in having 42 instead of $44-$ 46 vertebrae, 86-91 instead of 75-85 scales in longitudinal series on body, a deeper body, and a smaller eye. There is also a difference in habitat. Grammonus robustus was described by Smith and Radcliffe in Radcliffe (1913:168, pl. 13, fig. 4), type locality Philippines between Cebu and Leyte at a depth of $315 \mathrm{~m}$. It has since been reported from the Red Sea to Japan from trawling on soft bottom from 45 to $345 \mathrm{~m}$ (Nielsen et al. 1999, Nakabo 2002).

Senou (1998:1, figs.) reported a specimen collected in $20 \mathrm{~m}$ from a cave in Ie-shima, Ryukyu Islands, as Oligopus robustus. He published an underwater photograph taken in the cave by K. Yunokawa and provided a specimen photograph.

Nielsen and Cohen (2004) described Grammonus theilei from one specimen collected in $35 \mathrm{~m}$ from a limestone cave off southeastern Sulawesi. It differs from $G$. $n a$ garedai in having 66 dorsal rays, 41 anal rays, 21 pectoral rays, and the low count of 38 vertebrae.

Nielsen (2007) borrowed the specimen from Ie-shima identified as Grammonus robustus from the Kanagawa Prefectural Museum of Natural History and described it as a new species, G. yunokawai. We suspected that this species might be the same as the two specimens of Grammonus from caves in the $\mathrm{Ha}$ waiian Islands, in view of the similarity in habitat and from prepublication meristic data of G. yunokawai provided by Jørgen G. Nielsen. Our putative paratype (USNM 391918) was sent to him so that a direct comparison could be made with the holotype of $G$. yunokawai. He provided $\mathrm{X}$-rays of the two speci- 

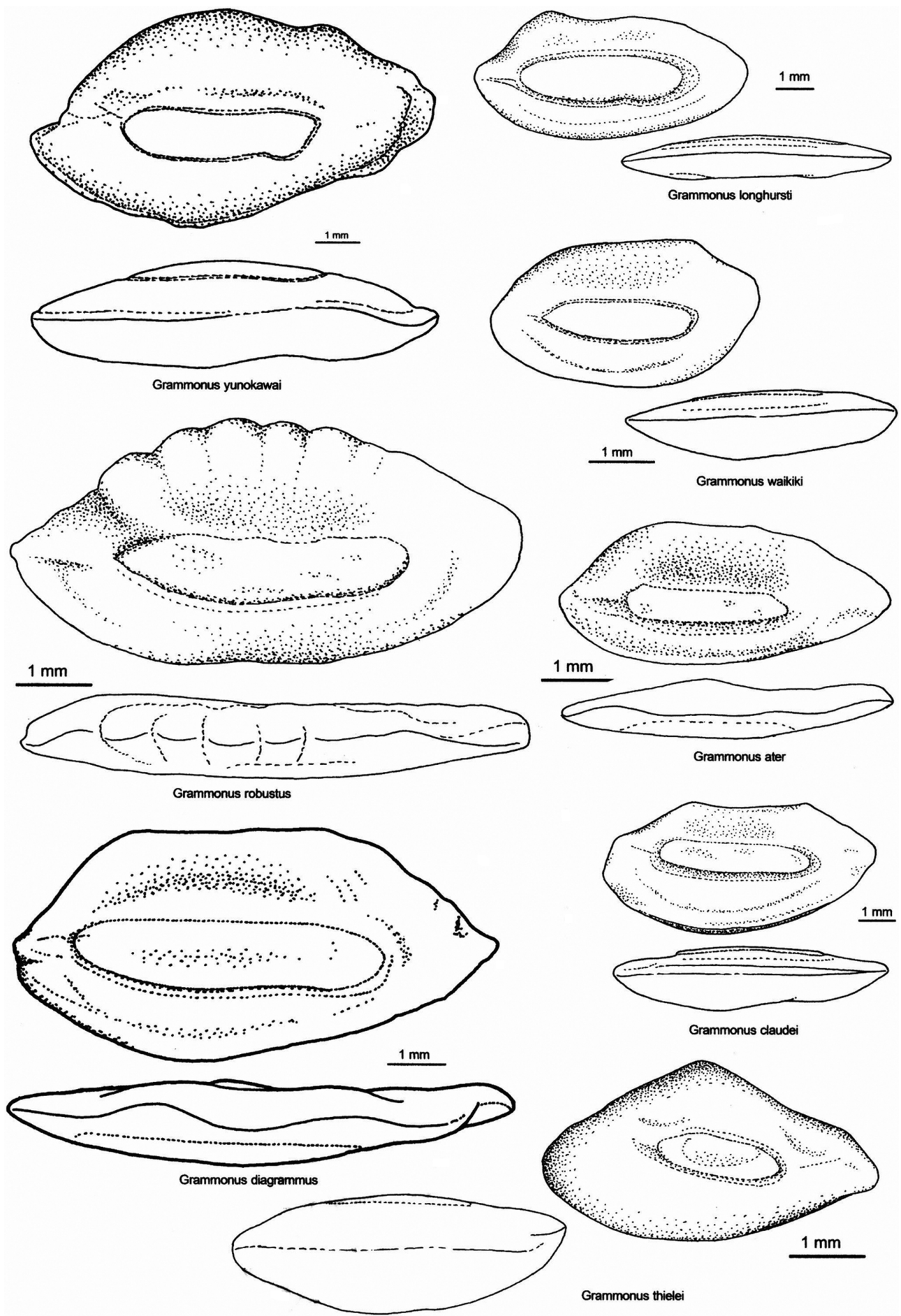

FIgURE 6. Otoliths of the species of Grammonus (Werner Schwarzhans). 

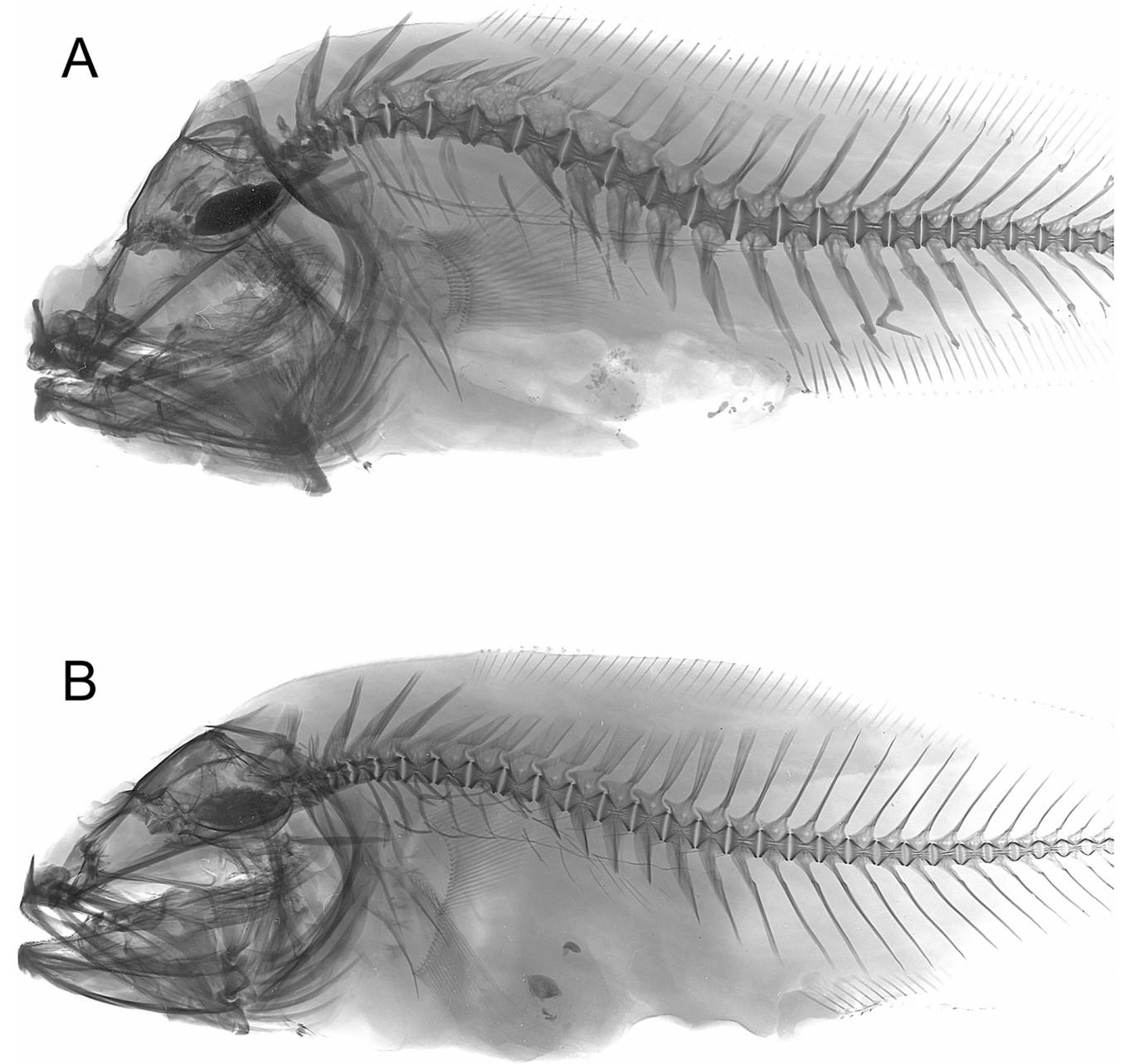

FIGURE 7. Comparison of X-rays of holotype of Grammonus yunokawai (A) and paratype of G. nagaredai (B) (Jørgen G. Nielsen).

mens (Figure 7). The greater body depth, steeper head profile, and more strongly convex nape of G. yunokawai are clearly evident. In addition, G. yunokawai has a broader maxilla (height at posterior end $8.4 \%$ SL, compared with $6.9-7.1 \%$ for $G$. nagaredai), the predorsal length is longer $(41.5 \% \mathrm{SL}$, compared with $38.0-38.4 \%$ ), and the pectoral fins are shorter $(18.9 \%$ SL, compared with $19.3-19.6 \%)$.

The otolith of $G$. nagaredai is most similar to that of G. yunokawai; it is thinner (height to thickness 3.2, compared with 2.0 for $G$. $y u$ - nokawai) and more elongate (2.0, compared with 1.8) (see Figures 5 and 6).

The holotype of $G$. nagaredai was collected at a depth of $6 \mathrm{~m}$ from a small lava rock cave about $0.5 \mathrm{~m}$ in width and $1 \mathrm{~m}$ in height, at the back of a long overhang of lava rock with a rubble bottom and only a little sand. It was first observed hovering near the ceiling of the small cave. The paratype was at the deepest recess of a large cave in $9 \mathrm{~m}$ with an entrance $3 \mathrm{~m}$ from the rocky shore; the cave extends about $30 \mathrm{~m}$ beneath the shore. There are small caves and holes at the back of the cave 
in which the paratype took refuge. The most common fish observed toward the back of the main cave was the cardinalfish Zapogon evermanni. A few individuals of Brotula multibarbata were also seen. The most common invertebrate was the hippolytid shrimp Parbippolyte mistica.

Bronson Nagareda maintained the holotype for a few days in his aquarium and noted that it was active at night (the tank has red light-emitting diodes for night viewing). When he added small live shrimp (Halocaridina rubra) to the tank, the fish ate the shrimp when they approached its head. It turned and struck at shrimp that approached from behind but often failed to catch the intended prey.

As mentioned, the paratype is a gravid female that had a very distended abdomen. It gradually released numerous larvae when it was placed in Marc James Hughes's tank. Only about one-fourth of the larvae that were liberated were collected. An estimated total of 3,000 larvae (from counting subsamples) was released. The ovary contains still more welldeveloped embryos, as can be seen by the dark eyes showing through the translucent ovarian wall. The first larvae swam actively in the tank, but later larvae sank to the bottom. The larvae do not have any yolk, and no remains of trophotaenia are evident. No attempt was made to remove embryos from the ovary, because some future worker may wish to make a study of them in situ, similar to that of Cohen and Wourms (1976).

\section{ACKNOWLEDGMENTS}

We are most grateful to Bronson Nagareda for his donation of the holotype of our new species and its live photographs; to Werner Schwarzhans for his description and drawing of the otolith of the paratype and his drawings of the otoliths of all the species of Grammonus; and to Jørgen G. Nielsen for advance information and the $\mathrm{X}$-ray of the holotype of G. yunokawai and for the loan of specimens of G. robustus from the Zoological Museum of the University of Copenhagen (zUMc). Thanks are also due Loreen R. O'Hara of the Bishop Museum for the X-ray of the holotype of $G$. nagaredai.

\section{Literature Cited}

Cohen, D. M. 1964. A review of the ophidioid fish genus Oligopus with the description of a new species from West Africa. Proc. U.S. Natl. Mus. 116:1-22.

Cohen, D. M., and J. P. Wourms. 1976. Microbrotula randalli, a new viviparous ophidioid fish from Samoa and New Hebrides, whose embryos bear trophotaeniae. Proc. Biol. Soc. Wash. 89 (5): 81-98.

Gosline, W. A. 1953. Hawaiian shallow-water fishes of the family Brotulidae, with the description of a new genus and notes on brotulid anatomy. Copeia 1953:215-225.

Mundy, B. C. 2005. A checklist of the fishes of the Hawaiian Archipelago. Bishop Mus. Bull. Zool. (6): 1-704.

Nakabo, T., ed. 2002. Fishes of Japan with pictorial keys to the species. English ed. 2 vols. Tokai University Press, Tokyo.

Nielsen, J. G. 2007. Grammonus yunokawai (Ophidiiformes: Bythitidae), a new marine cavefish from the Ryukyu Islands. Ichthyol. Res. 54:374-379.

Nielsen, J. G., and D. M. Cohen. 2004. Grammonus thielei (Ophidiiformes: Bythitidae) - a new bythitid cavefish from off Sulawesi, Indonesia. Beagle (Rec. Mus. Art Galleries N. Terr.) 20:83-86.

Nielsen, J. G., D. M. Cohen, D. F. Markle, and C. R. Robins. 1999. FAO species catalogue. Vol. 18. Ophidiiform fishes of the world (Order Ophidiiformes). An annotated and illustrated catalogue of pearlfishes, cusk-eels, brotulas and other ophidiiform fishes known to date. FAO Fish. Synop. No. 125.

Radcliffe, L. 1913. Descriptions of seven new genera and thirty-one new species of fishes of the families Brotulidae and Carapidae from the Philippines Islands and the Dutch East Indies. Proc. U.S. Natl. Mus. 44:135-176.

Randall, J. E. 2007. Reef and shore fishes of the Hawaiian Islands. Sea Grant College Program of the University of Hawai'i, Honolulu.

Senou, H. 1998. Oligopus robustus (Smith et Radcliffe, 1913). I.O.P. Diving News 9 (11): 1 [in Japanese]. 